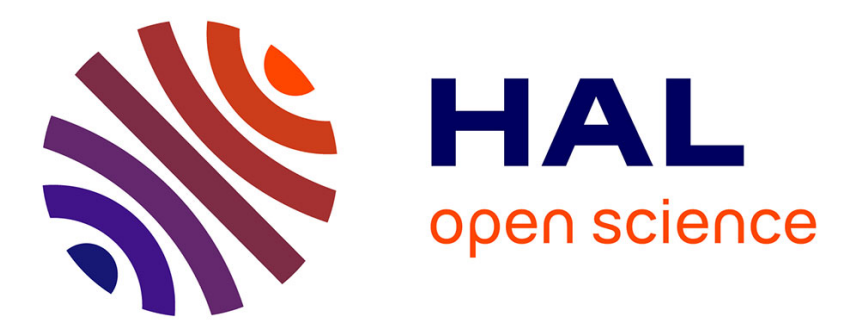

\title{
Synthesizing lead white pigments by lead corrosion: New insights into the ancient manufacturing processes
}

Victor Gonzalez, Gilles Wallez, Thomas Calligaro, Didier Gourier, Michel

Menu

\section{- To cite this version:}

Victor Gonzalez, Gilles Wallez, Thomas Calligaro, Didier Gourier, Michel Menu. Synthesizing lead white pigments by lead corrosion: New insights into the ancient manufacturing processes. Corrosion Science, 2019, 146 (Janvier 2019), pp.10-17. hal-01977449

\section{HAL Id: hal-01977449 https://hal.sorbonne-universite.fr/hal-01977449}

Submitted on 10 Jan 2019

HAL is a multi-disciplinary open access archive for the deposit and dissemination of scientific research documents, whether they are published or not. The documents may come from teaching and research institutions in France or abroad, or from public or private research centers.
L'archive ouverte pluridisciplinaire HAL, est destinée au dépôt et à la diffusion de documents scientifiques de niveau recherche, publiés ou non, émanant des établissements d'enseignement et de recherche français ou étrangers, des laboratoires publics ou privés. 


\title{
Synthesizing lead white pigments by lead corrosion: new insights into the ancient manufacturing processes
}

Victor Gonzalez $z^{1,2,3,4}$, Gilles Wallez ${ }^{1,4,5^{*}}$, Thomas Calligaro ${ }^{1,4}$, Didier Gourier ${ }^{1,4}$, Michel $\mathrm{Menu}^{1,4}$

${ }^{1}$ Centre de Recherche et de Restauration des Musées de France, C2RMF, Palais du Louvre, 75001 Paris, France

${ }^{2}$ Department of Materials Science and Engineering, Delft University of Technology, 2600 AA, Delft, The Netherlands

${ }^{3}$ Rijksmuseum, 1070 DN, Amsterdam, The Netherlands

${ }^{4}$ Chimie ParisTech, PSL University, CNRS, Institut de Recherche de Chimie Paris, 75005 Paris, France

${ }^{5}$ UFR 926, Sorbonne Universités, 75005 Paris, France

* corresponding author, gilles.wallez@sorbonne-universite.fr

ENSCP Chimie ParisTech, 11 rue Pierre et Marie Curie, 75005 Paris, France

\begin{abstract}
Traditional "stack" manufacturing process $\left(16-19^{\text {th }}\right.$ c.) of lead white pigment by lead corrosion is explored by exposing metal to acetic acid, carbon dioxide, dioxygen and water vapor. Global reaction scheme is revealed, along with stratification of corrosion products with $\mathrm{CO}_{2}$ gradient, leading to flakiness of corrosion layer. Kinetic and epitaxial features rule the polyphased structure, explaining hydrocerussite-rich compositions and absence of plumbonacrite in classical easel paintings. Microstructure of cerussite appears as a differentiation criterion between stack-made and industrial precipitation-synthesized lead whites. Particular conditions reported in ancient writings are tested and discussed to understand unusual processes.
\end{abstract}

\section{Contributors}

This work is based upon VG's PhD thesis work directed by MM and supervised by TC and GW. Experiments, data analysis and wording were performed by VG and GW. DG and TC contributed to this work through numerous helpful discussions and re-reading. 


\section{Introduction}

"Lead white" (LW) generally refers to a pigment made of lead carbonate, either cerussite $\mathrm{PbCO}_{3}(\mathrm{C})$ or hydrocerussite $\mathrm{Pb}_{3}\left(\mathrm{CO}_{3}\right)_{2}(\mathrm{OH})_{2}(\mathrm{HC})$, more often a combination of these phases or even a mixture with a white extender like calcite, gypsum or barite. In the following, we will only consider the non-extended product of lead corrosion. Note that $\mathrm{C}$ and $\mathrm{HC}$ carbonates, along with the less common plumbonacrite $\mathrm{Pb}_{5} \mathrm{O}\left(\mathrm{CO}_{3}\right)_{3}(\mathrm{OH})_{2}(\mathrm{PN})$, have long remained undistinguished or mistaken in the literature due to the overlaping of many of their XRD lines, until their formulas and crystal structures were formally established.

Prior being banned because of its toxicity and replaced by zinc and titanium whites in the $20^{\text {th }} \mathrm{c}$., LW had been by far the most employed white pigments of all times owing to its chemical stability, low solubility in water and organic binders and high opacity and high refractive index due to the atomic number of lead. Natural lead carbonates were already prized during the Egyptian antiquity as cosmetics, before their use spread to the Greek and Roman worlds [1,2], notably as pigments for paintings. To satisfy the ever growing demand, various manufacture processes starting from metallic lead were developped, as reported by Theophrastus in the $3^{\text {rd }} \mathrm{c}$. BP [3], then by Pliny the Elder during the $1^{\text {st }} \mathrm{c}$. [4]. Both the Greek psimythion and the Roman cerussa were produced by exposing metallic lead to vinegar vapors. Sometimes, a source of carbon dioxide (resulting from the decay of organic matter or from fire fumes) was also implemented. It is also during Antiquity that first uses of LW in painted objects are attested, in particular in the Fayum portraits of the $2^{\text {nd }} \mathrm{c}$. AD [5]. LW was then used in Western easel paintings in the late Middle Ages, then became ubiquitous in European art, as confirmed by several recent analytical works based upon synchrotron diffraction [6-9].

With time, a source of carbon dioxide was systematically used, typically horse manure, tan bark or urine in decomposition, or a mineral carbonate poured in vinegar [10]. In the $16^{\text {th }} \mathrm{c}$., the so-called "stack process" was named after its industrial application featuring piles of jars containing the lead coils and vinegar, but it was also known as the "Dutch process" owing to the massive production originating from the Netherlands in the $17^{\text {th }} \mathrm{c}$.. Note that Persian treatises of the $12^{\text {th }}-16^{\text {th }}$ c. reported the use of chlorinated raw materials in the synthesis of white lead-based pigments, that resulted in different final products like laurionite $\mathrm{Pb}(\mathrm{OH}) \mathrm{Cl}$, blixite $\mathrm{Pb}_{8} \mathrm{O}_{5}(\mathrm{OH})_{2} \mathrm{Cl}_{4}$ and phosgenite $\mathrm{Pb}_{2} \mathrm{Cl}_{2} \mathrm{CO}_{3}$ [11].

From a chemical point of view, the Dutch process conceivably consists in the combined actions of carbon dioxide and acetic acid vapor, but also probably of dioxygen, as the two former compounds are not strong enough as oxidizers. Water vapor is involved also. Most of the facts and data reported by pre-modern and modern authors and mentionned in this paper can be found in the comprehensive survey of pre-industrial LW fabrication processes by M. Stols-Witlox [12]. Unfortunately, relevant parameters as temperature (the decomposition of manure is exothermic), partial pressure of gas reagents and presence of other molecules can hardly be inferred from these writings. Besides, various ways to improve the quality of the asobtained LW can be found in the ancient treaties. Progresses in industrial chemistry at the end of the $18^{\text {th }} \mathrm{c}$. also gave rise to faster mass-production processes based upon the precipitation of the lead carbonates by aqueous carbonation of soluble salts [13], but these topics are out of the scope of this work, which focuses on the corrosion mechanism.

To date, the reaction between lead and acetic acid vapor was only explored under low pressure, mostly in order to clear up its implication in corrosion concerns [13-16]. Various lead acetates were observed, which eventually carbonated into PN and HC. Note that in these 
studies, carbon dioxide was only involved at the level of an atmospheric pollutant, therefore at a very low partial pressure. So, despite the significance of LW in both basic chemistry, industrial processes and cultural heritage, the chemistry of the $\left(\mathrm{Pb}, \mathrm{CH}_{3} \mathrm{COOH}, \mathrm{H}_{2} \mathrm{O}, \mathrm{CO}_{2}\right.$, $\mathrm{O}_{2}$ ) system that rules the synthesis and post-synthesis treatments remains largely unknown, along with the mechanism of the chemical transformations involving the various precursors and LW components.

The present work is not intended to mimic the many processes reported in the literature, neither to measure the influence of each of the numerous parameters, but to propose general trends by analyzing stepwise the reactions at stake. The primary goals are to understand the mechanism of the carbonation process and the structure of the corrosion layer, but we will also try to answer pending questions dealing with the use of LW as a pigment: the prevalence of intermediate carbonate $\mathrm{HC}$ and the absence of $\mathrm{PN}$ in paintings. We will also try to interpret certain practices related by ancient writers, which seem to contradict modern chemistry. At last, based upon the microstructure of cerussite, an identification criterion to distinguish traditional LW pigments resulting from corrosion from those obtained by more recent aqueous routes will be proposed. To our knowledge, this work is the first reasoned experiment-based approach of the corrosion process reported by the ancient writings.

\section{Experimental}

The corrosion process In the experimental setup, lead foils, $2 \mathrm{~mm}$ thick (Goodfellow, 99.95+) previously scraped with P150 ISO sandpaper and cleaned with acetone were placed in a $60 \mathrm{~L}$ vessel, along with a beaker containing $100 \mathrm{~mL}$ of acetic acid $(10 \mathrm{vol} \%)$ and another one with a $4 \mathrm{~L}$ of sugar aqueous solution $(1.5 \mathrm{w} \%)$, preheated at $40{ }^{\circ} \mathrm{C}$ and mixed with $10 \mathrm{~g}$ yeast, then kept at $25^{\circ} \mathrm{C}$, intended to act as a slow source of water vapor and carbon dioxide. Ventilation slits were left open to allow a continuous air supply, keeping the dioxygen concentration close to the atmospheric level. Relative humidity was measured at 96(1) \% and $\mathrm{CO}_{2}$ concentration in the 8000-10000 ppm (v/v) range using an AZ-77535 probe. The concentration of the acetic acid vapor was estimated at about $700 \mathrm{ppm}$ from Campbell et al. vapor-liquid equilibrium measurements at $25^{\circ} \mathrm{C}$ [17].

Synthesis by aqueous route $\mathrm{C}$ was obtained by mixing aqueous solutions of $\mathrm{Pb}\left(\mathrm{NO}_{3}\right)_{2}$ and $\mathrm{Na}_{2} \mathrm{CO}_{3}$ (Merck, $99.95 \%$ ) in stoichiometric proportions. The precipitate was filtered and washed with a large volume of permuted water for $\mathrm{C}$, then rinsed with alcohol and dried in stove at $60{ }^{\circ} \mathrm{C}$.

$X$ ray diffraction patterns from powders and corrosion films were recorded using a Panalytical Xpert Pro Bragg-Brentano diffractometer with Ge(111)-monochromated CuK $\alpha 1$ radiation. XRD allowed to follow the evolution of corrosion on the foils themselves, but only qualitative observations were made because of the geometric imperfection of the surface, the texturation of the corrosion film and the impossibility to correct the intensities for the absorbance of the superposed layers. On the other hand, the powder samples collected on the foils were suitable for Rietveld analysis, but due to the platelet habitus of the HC crystallites, the measurements of the $\mathrm{HC} / \mathrm{C}$ ratios were made on $\mathrm{LW}$ :Nescafé $^{\mathrm{TM}}=3: 1$ weight ratio mixtures. The preferred orientation of $\mathrm{HC}$ in the so-obtained samples were low enough (typically $<6 \%$ ) to be corrected using the March-Dollase function [18]. Quantitative measurements of composition and microstructure analysis were performed by the Rietveld method, using the Fullprof suite [19]. The refinements were based upon the crystal data found in the literature for cerussite [20], hydrocerussite [21] and plumbonacrite [22]. The peaks 
profiles were fitted with the Thompson-Cox-Hastings function with spherical harmonic expansion to take into account the platelet shape of HC. A preliminary test of quantitative analysis made on a $\mathrm{HC}: \mathrm{C}=50: 50 \mathrm{w} \%$ calibration mixture gave a satisfactory 49.3:50.7 ratio. The small historical LW samples were analyzed using a lab-built diffractometer at the C2RMF, a combination of a CuK $\alpha 200-\mu \mathrm{m}$ diameter parallel beam source and a Rigaku RAxis IV++ imaging plate. $i=f(2 \theta)$ patterns were derived from the diffraction rings using the FIT2D software [23].

Ultraviolet irradiation was carried out using a $30 \mathrm{~W}$ Thermo Scientific mercury fluorescence lamp. Lead acetate trihydrate (Alfa Aesar, $99 \%$ ) crystals ground in mortar were exposed during 24 hours to either the 280 or the $365 \mathrm{~nm}$ radiations.

\section{Results and Discussion}

Lead corrosion The following sequences are observed (see Fig. 1 for the global flowchart, Fig. 2 for the XRD patterns). Because notable variability was observed between repeated experiments due to varying ambient temperature and other poorly controlled parameters, the times given below are only indicative.

- Step 1. After a few minutes, a thin iridescent film becomes visible. The identification of this first compound is difficult due to the short time before carbonates start to grow. XRD lines matching with PDF\#00-018-1739 account for lead oxide acetate hydrate $\mathrm{Pb}_{4} \mathrm{O}\left(\mathrm{CH}_{3} \mathrm{COO}\right)_{6} \mathrm{H}_{2} \mathrm{O}(\mathrm{LOAH})$, but this formula, like those of several lead acetates, should be taken with caution as their basic characterization was never improved since their discovery in 1965 [24]. Nevertheless, this compound (or mixture) is the same as the one observed during the early stages of lead corrosion in the "absence" of $\mathrm{CO}_{2}$ $[14,16]$. Global reaction can be written (all equations are normalized to $1 \mathrm{~Pb}$ in the following):

$$
\mathrm{Pb}+1 / 2 \mathrm{O}_{2}+3 / 2 \mathrm{CH}_{3} \mathrm{COOH} \rightarrow 1 / 4 \mathrm{~Pb}_{4} \mathrm{O}\left(\mathrm{CH}_{3} \mathrm{COO}\right)_{6} \cdot \mathrm{H}_{2} \mathrm{O}+1 / 2 \mathrm{H}_{2} \mathrm{O}
$$

As will be shown, $\mathrm{O}_{2}$ is mandatory during this phase as an oxidizer. According to Tétreault et al., lead acetates grow much faster on a tarnished surface (obtained by exposing lead to ambient air prior to acetic acid vapor) [14], but so far, it cannot be decided whether it forms in a one- or two-step reaction once the pre-formed oxide film is fully transformed. Reaction (1) also occurs in absence of $\mathrm{CO}_{2}$, but the corrosion is much slower. An alternative reaction was observed in the presence of water vapor condensation on the foils, which favors the growth of lead acetate trihydrate $\mathrm{Pb}\left(\mathrm{CH}_{3} \mathrm{COO}\right)_{2} .3 \mathrm{H}_{2} \mathrm{O}$ (LATH, PDF\#00-014-0829):

$$
\mathrm{Pb}+1 / 2 \mathrm{O}_{2}+2 \mathrm{CH}_{3} \mathrm{COOH}+2 \mathrm{H}_{2} \mathrm{O} \rightarrow \mathrm{Pb}\left(\mathrm{CH}_{3} \mathrm{COO}\right)_{2} \cdot 3 \mathrm{H}_{2} \mathrm{O}
$$




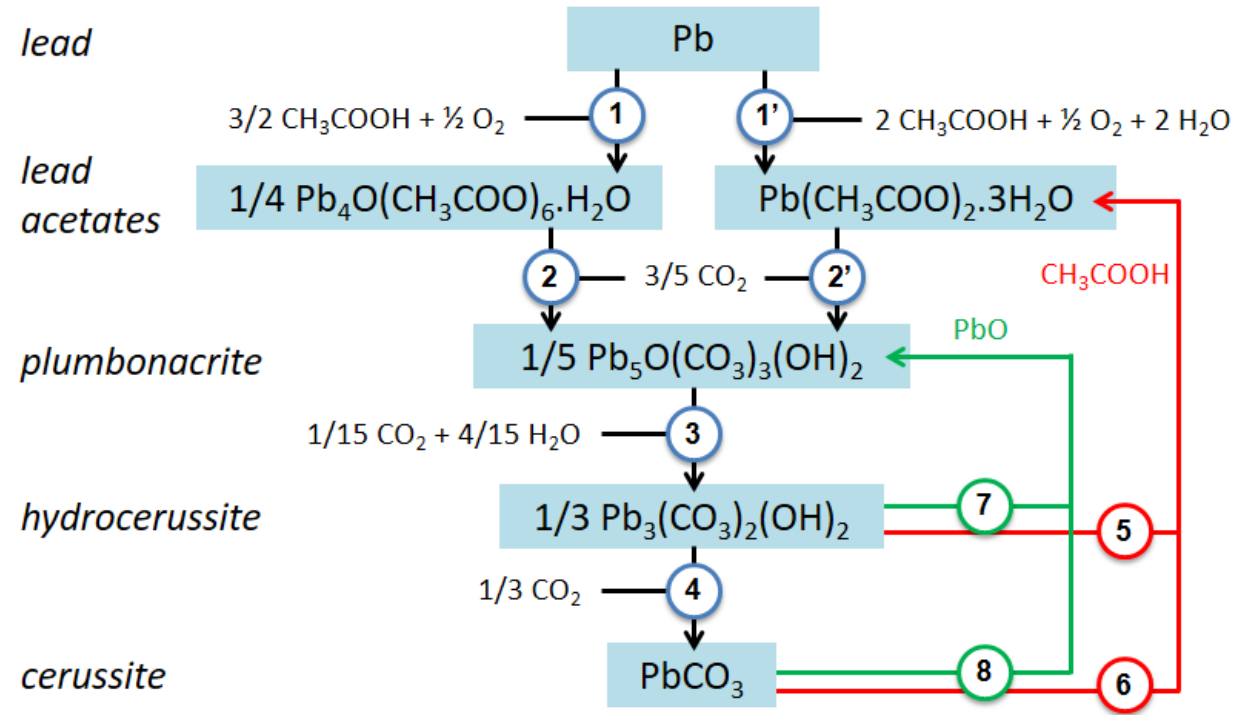

Fig. 1. Flowchart of the reaction paths observed during the formation of lead white pigments by corrosion under air, $\mathrm{CO}_{2}, \mathrm{CH}_{3} \mathrm{COOH}$ and $\mathrm{H}_{2} \mathrm{O}$ vapors.

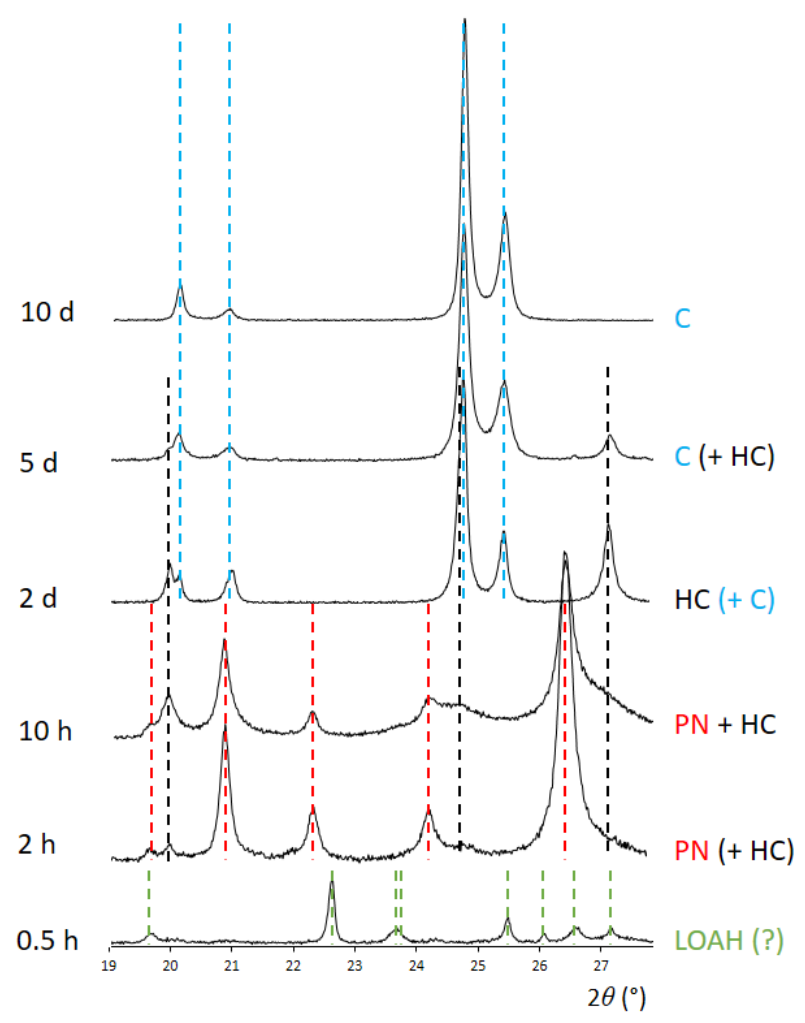

Fig. 2. Evolution of the XRD pattern of the external lead surface during 10 days, with main diffraction lines of corrosion compounds.

- Step 2. At about $1 \mathrm{~h}$, carbonation becomes detectable by XRD, with the growth of plumbonacrite (PDF\#04-017-4336) from the acetate(s): 


$$
\begin{gathered}
1 / 4 \mathrm{~Pb}_{4} \mathrm{O}\left(\mathrm{CH}_{3} \mathrm{COO}\right)_{6} \mathrm{H}_{2} \mathrm{O}+3 / 5 \mathrm{CO}_{2}+7 / 5 \mathrm{H}_{2} \mathrm{O} \rightarrow 1 / 5 \mathrm{~Pb}_{5} \mathrm{O}\left(\mathrm{CO}_{3}\right)_{3}(\mathrm{OH})_{2}+3 / 2 \\
\mathrm{CH}_{3} \mathrm{COOH}
\end{gathered}
$$

PN probably exhibits its usual platelet habitus [22] with the $\boldsymbol{c}$ (six-fold) axis perpendicular to the foil surface as attested by the enhancement and the broadening of the (00l) diffraction lines. A faint amount of hydrocerussite (PDF\#04-016-7055) is also detected, but quantification is hampered by the preferred orientation and also the probable non-reciprocal absorbance of the two phases. Acetates are no more detected. In the following ( 2 to $22 \mathrm{~h}$ ), the diffracted intensities of $\mathrm{HC}$ increase, while those of PN decrease, according to equation:

$$
1 / 5 \mathrm{~Pb}_{5} \mathrm{O}\left(\mathrm{CO}_{3}\right)_{3}(\mathrm{OH})_{2}+1 / 15 \mathrm{CO}_{2}+4 / 15 \mathrm{H}_{2} \mathrm{O} \rightarrow 1 / 3 \mathrm{~Pb}_{3}\left(\mathrm{CO}_{3}\right)_{2}(\mathrm{OH})_{2}
$$

During this step, the corrosion film grows thick enough to absorb the diffraction peaks of metallic lead.

- Step 3. At about 24 h, PN is no more detected, but cerussite (PDF\#04-007-4913) appears:

$$
\text { - } 1 / 3 \mathrm{~Pb}_{3}\left(\mathrm{CO}_{3}\right)_{2}(\mathrm{OH})_{2}+1 / 3 \mathrm{CO}_{2} \rightarrow \mathrm{PbCO}_{3}+1 / 3 \mathrm{H}_{2} \mathrm{O}
$$

$\mathrm{HC}$ and $\mathrm{C}$ coexist until complete consumption of lead (about two months), with a progressive decrease of the HC:C ratio. The film turns into a thick, porous and brittle layer that does not adhere anymore to the metal, forming flakes that can be easily removed, as reported in the ancient literature [12].

- Step 4. After being separated from the substrate and further exposed to corrosion, the $\mathrm{HC}: \mathrm{C}$ ratio tends to zero, and the flakes turn progressively into a pure $\mathrm{C}$ phase after about a week.

Logically, the corrosion route, as probably in the stack process, yields products with a carbonation rate that increases with time, in the order PN / HC / C. In this way, it offers a remarkable similarity with the order of prevalence in aqueous solutions with decreasing $p \mathrm{H}$.

Stratification of the corrosion product After 3 weeks, the corrosion film has become several $\mathrm{mm}$ thick (Fig. 3). In order to observe possible variations of the composition perpendicular to the surface, the film was delaminated in three layers, ground separately and analyzed using XRD/Rietveld, along with the residual metal. PN was the only compound detected at the surface of the foil itself. A small amount was measured in the lower layer, dropping to zero in the intermediate and upper ones (Fig. 4). The flakes themselves appeared to be made of $\mathrm{HC}$ and $\mathrm{C}$ with an increasing $\mathrm{C}: \mathrm{HC}$ ratio corresponding to a gradient of carbonate concentration from metal to surface: C:HC:PN $=43: 55: 2 \pm 2 \mathrm{w} \%$ (internal flake), 85:15:0 $\pm 2 \mathrm{w} \%$ (intermediate flake), 100:0:0 w\% (external flake). It can therefore be reasonably concluded that the previously detailed reactions take place not only successively in time, but also simultaneously at various depths. This mechanism and the resulting multi-phase stratification are probably favored by the high permeability to gases of the low-density microstructure. 


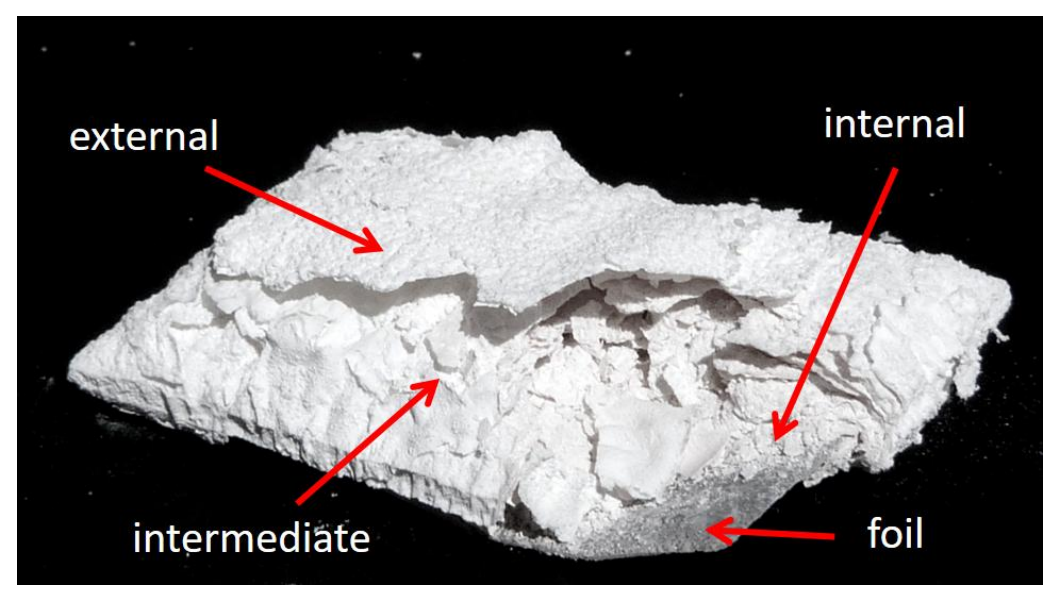

Fig. 3. Corrosion flakes grown on a lead foil (3 weeks).

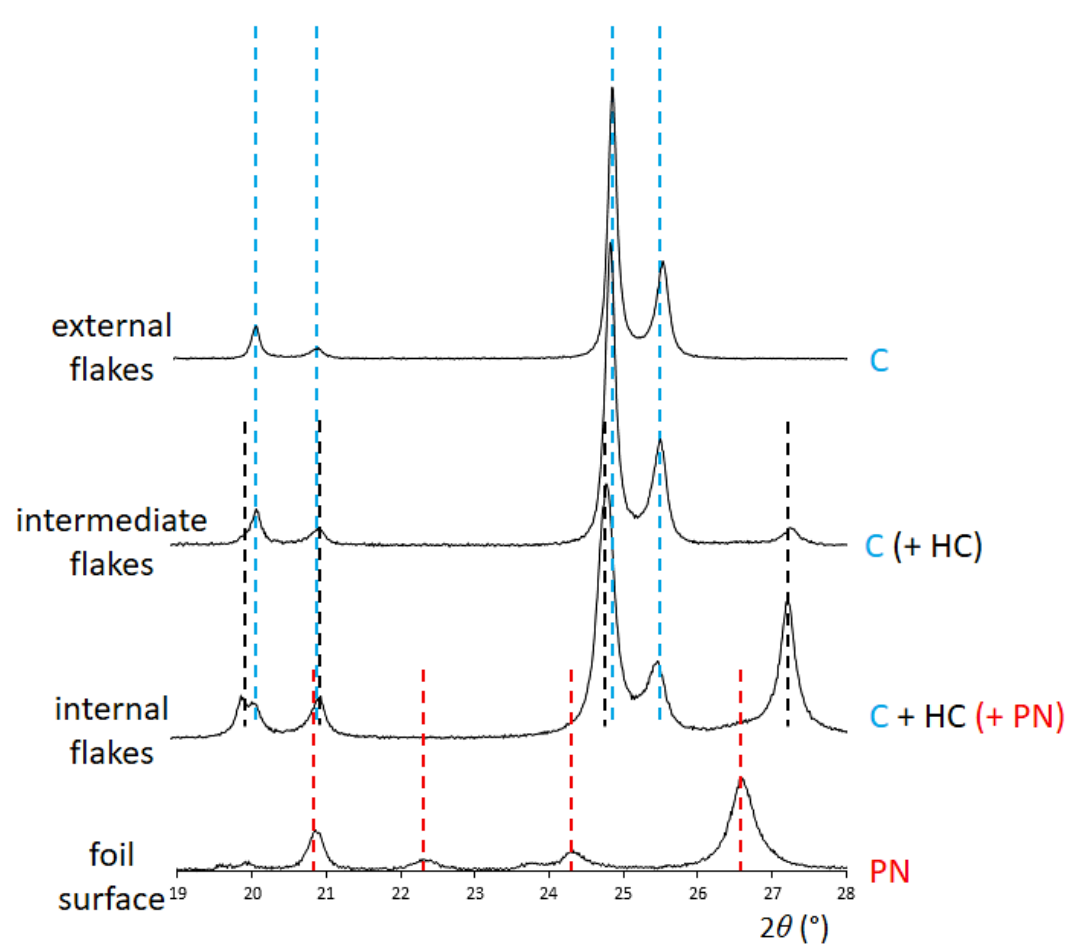

Fig. 4. XRD patterns and compositions of the foil surface and 3 successive layers of LW flakes extracted after 3 weeks.

Although being noticeable during the early stages of the process, lead acetate readily transforms into carbonates in the presence of $\mathrm{CO}_{2}$. Nevertheless, it plays an active role throughout the process, insofar as the corrosion proceeds much slowly in the absence of acetic acid, in agreement with Faivre et al. who consider it as a catalytic agent [25]. However when acetic acids is in excess, its vapor becomes detrimental to the LW already formed. Indeed we observed that both $\mathrm{C}$ and $\mathrm{HC}$ undergo a reverse transformation into LATH when the $\mathrm{CO}_{2}$ supply is stopped. 


$$
\begin{gathered}
1 / 3 \mathrm{~Pb}_{3}\left(\mathrm{CO}_{3}\right)_{2}(\mathrm{OH})_{2}+2 \mathrm{CH}_{3} \mathrm{COOH}+5 / 3 \mathrm{H}_{2} \mathrm{O} \rightarrow \mathrm{Pb}\left(\mathrm{CH}_{3} \mathrm{COO}\right)_{2} \cdot 3 \mathrm{H}_{2} \mathrm{O}+2 / 3 \mathrm{CO}_{2} \\
\mathrm{PbCO}_{3}+2 \mathrm{CH}_{3} \mathrm{COOH}+2 \mathrm{H}_{2} \mathrm{O} \rightarrow \mathrm{Pb}\left(\mathrm{CH}_{3} \mathrm{COO}\right)_{2} .3 \mathrm{H}_{2} \mathrm{O}+\mathrm{CO}_{2}
\end{gathered}
$$

These reactions could have occurred in the ancient processes not involving a source of $\mathrm{CO}_{2}$, but also in the stack process when the $\mathrm{CO}_{2}$ supply is exhausted (e.g. end of manure decomposition). Conceivably, the tendency to synthesize either lead carbonates or acetates depends on the concentration ratio of the present gases, which can only be roughly controlled in pre-industrial plants. As a consequence, LATH or other lead acetates were likely to occur in as-prepared LWs, whatever the process was employed. Although the effect of the presence of lead acetates in the pigment remains controversial, ancient authors (like King (1653) and Le Pileur d'Apligny (1779), cited by Stols-Witlox [12]) generally emphasize on the necessity to rinse or grind the pigment in water, probably in order to eliminate this very soluble compound. One can note that in the $19^{\text {th }}$ and $20^{\text {th }} \mathrm{c}$ LATH has been reported to be mixed with binders to accelerate the drying of paint layers. However, detection and identification of lead driers is challenging, in particular in presence of another lead-based pigment such as LW, and can only be hypothesized [25].

Before a $\mathrm{CO}_{2}$ source was systematically implemented to the corrosion facility in the late Middle Ages, acetic acid vapor issued from vinegar generally appeared as the only reagent with lead [4,26]. In such conditions, according to modern studies [14-16] and to the present work corrosion is slow and the final product mainly consists in acetate(s), along with minor amounts of PN and HC. However, quoting ancient authors like Dioscorides [27], Theophrastus [3] and anonymous $14^{\text {th }}$ c. Secretum Philosophorum, Thompson [28] and Clarke [29] stress that the so-obtained materials generally underwent a subsequent treatment. The most straightforward way (Dioscorides" "winter process") consisted in roasting the powder, that is, exposing the lead acetate(s) to combustion gases, thus allowing the expected carbonation.

On the other hand, Dioscorides notes that sunlight can have the same effect as roasting on the corrosion product. Recently, this "summer process" was reproduced successfully by Katsaros et al. [2] who obtained a mixture of $\mathrm{HC}$ and $\mathrm{C}$ by exposing the primary product to sunlight for 10 days, with a measured temperature in the $27-55{ }^{\circ} \mathrm{C}$ range. This result is surprising considering that the mechanism of the conversion of lead acetate(s) into carbonate(s) has not yet been reported and deservea few comments. First, from our own experiments, LATH does not turn readily into $\mathrm{PN}$ or $\mathrm{HC}$ when exposed to air at $20{ }^{\circ} \mathrm{C}$. Note that from Antiquity to the pre-industrial period, the lower $\mathrm{CO}_{2}$ concentration in air, about 250 vs. 400 ppm nowadays, would have made the process even slower. Secondly, the thermal transformations of lead acetates in open air are now well documented thanks to MartínezCasado et al. [30], who revealed sequentially anhydrous $\mathrm{Pb}\left(\mathrm{CH}_{3} \mathrm{COO}\right)_{2}$, oxyacetate $\mathrm{Pb}_{2} \mathrm{O}\left(\mathrm{CH}_{3} \mathrm{COO}\right)_{2}$ and finally $\mathrm{PbO}$ as products - excluding any spontaneous transformation of the acetate group into carbonate. Thirdly, UV irradiation at 280 and $365 \mathrm{~nm}$ (this work) at room temperature failed to induce a chemical transformation of LATH. Therefore, the expected reaction is probably due to a combined effect of UV(-vis) exposure and moderate heating, calling for further investigations to clear up the mechanism.

Evolution in air of a partly corroded foil A lead foil was partly corroded in the four-gas environment, then extracted from the reactor and left open to air during three months. XRD reveals the presence of PN in the flakes, contrary to freshly corroded samples. From the Scherrer's broadening of the $00 \mathrm{l}$ diffraction lines, the $L_{001}$ mean thickness of the crystallites can be estimated at $16 \pm 1 \mathrm{~nm}$. The presence of PN could result from the resumption of the 
corrosion process in the absence of $\mathrm{CO}_{2}$ and $\mathrm{CH}_{3} \mathrm{COOH}$, yielding at first alkaline $\mathrm{PbO}$ at the metal's surface, which in turn reacts with adherent $\mathrm{HC}$ according to:

$$
3 / 10 \mathrm{~Pb}_{3}\left(\mathrm{CO}_{3}\right)_{2}(\mathrm{OH})_{2}+1 / 10 \mathrm{PbO} \rightarrow 1 / 5 \mathrm{~Pb}_{5} \mathrm{O}\left(\mathrm{CO}_{3}\right)_{3}(\mathrm{OH})_{2}+1 / 10 \mathrm{H}_{2} \mathrm{O}
$$

As suggested by the very low amounts of $\mathrm{C}$ found in presence of $\mathrm{PN}$, basic $\mathrm{PbO}$ and acid $\mathrm{C}$ are also very likely to react with each other:

$$
3 / 5 \mathrm{PbCO}_{3}+2 / 5 \mathrm{PbO}+1 / 5 \mathrm{H}_{2} \mathrm{O} \rightarrow 1 / 5 \mathrm{~Pb}_{5} \mathrm{O}\left(\mathrm{CO}_{3}\right)_{3}(\mathrm{OH})_{2}
$$

It is worth noting that metallic lead and the three lead carbonates co-exist as long as the former is still present. This apparent violation of the phases' rule probably results from the fact that the three carbonates grow at different depths of the corrosion layer: (i) PN at the lead surface or from a possible intermediate acetate film, (ii) $\mathrm{HC}$ over PN, then delaminating into flakes, and (iii) $\mathrm{C}$ by converting $\mathrm{HC}$ starting from the external surface. As the growth is driven by the diffusion of gas reagents throughout the corrosion layer and their consumption during the successive reactions, the $\mathrm{CO}_{2}$ flux is expected to decrease with depth, while reactions 1-4 occur at various depths. So, from a thermodynamic point of view, this fourphase system appears to be ruled by a series of transient equilibria related to local $\mathrm{CO}_{2}$ potential.

\section{Corrosion without dioxygen and carbon dioxide}

Ancient treaties cited by Clarke mention that the jars containing the lead coils and the vinegar were often "tightly sealed" to prevent gas circulation [29]. This procedure obviously aimed at avoiding excessive losses of acetic acid vapors during the several weeks required by the process, but the $\mathrm{O}_{2}$ and $\mathrm{CO}_{2}$ supply was likely reduced at the same time, leading to question about an hypothetical route to LW by exposing lead to acetic acid and water vapors only. The present work only involves a lead foil and an acetic acid solution; the container was flushed with $\mathrm{N}_{2}$, then tightly sealed. After 1 day, (001)-textured $\mathrm{Pb}\left(\mathrm{CH}_{3} \mathrm{COO}\right)_{2} \cdot 3 \mathrm{H}_{2} \mathrm{O}$ forms (reaction 1'), along with a faint amount of $\mathrm{HC}(2$ ' \& 3) which disappears after 2 days (5). From XRD, the powder obtained at 30 days matches with unindexed PDF\#00-018-1738 [24]. Once attributed to a possible anhydrous lead acetate, this pattern was recently shown to correspond to a mixture of the actual $\mathrm{Pb}\left(\mathrm{CH}_{3} \mathrm{COO}\right)_{2}$ and oxyacetate $\mathrm{Pb}_{4} \mathrm{O}\left(\mathrm{CH}_{3} \mathrm{COO}\right)_{2}$ [30]. Carried out at $50{ }^{\circ} \mathrm{C}$ to simulate the heating induced by manure decomposition, corrosion only yields pre-mentioned LOAH. Whatever the temperature, the corrosion film remains however very thin, even at longer time, showing that the process is not sustainable without a significant supplementation of oxidizer. The faint amount of acetates observed probably results from the reaction with preexisting lead oxide. As a conclusion, $\mathrm{O}_{2}$ must be considered as a key reagent to the formation of LW, which cannot therefore be carried out in really airtight vessels. So, despite the efforts of the ancient manufacturers, their containers were probably not as well sealed as they expected. For instance, Katsaros et al. mention that the thin skin covering the vessel used for their mock up is "quasi-transparent to air (i.e. it breaths)" [2].

Plumbonacrite The first carbonate formed, PN, is almost absent from the flakes despite a thin film remains at the metal's surface during all the corrosion process. PN adheres so firmly to ductile lead that we did not succeed in separating the two phases by mechanical means. On (111) laminated lead, hexagonal PN grows with a slight preferred orientation of the $c^{*}$ direction perpendicular to the surface. Indeed, the interface is probably epitaxial, 
considering both the common three-fold symmetry and the fortuitous lattice matching with the $z \approx 0.1$ or 0.3 plane of $\mathrm{PN}\left(3 d_{\mathrm{Pb}-\mathrm{Pb}}(\mathrm{Pb}) / 2 d_{\mathrm{Pb}-\mathrm{Pb}}(\mathrm{PN})=1.000\right.$, Fig. 5 , left $)$.
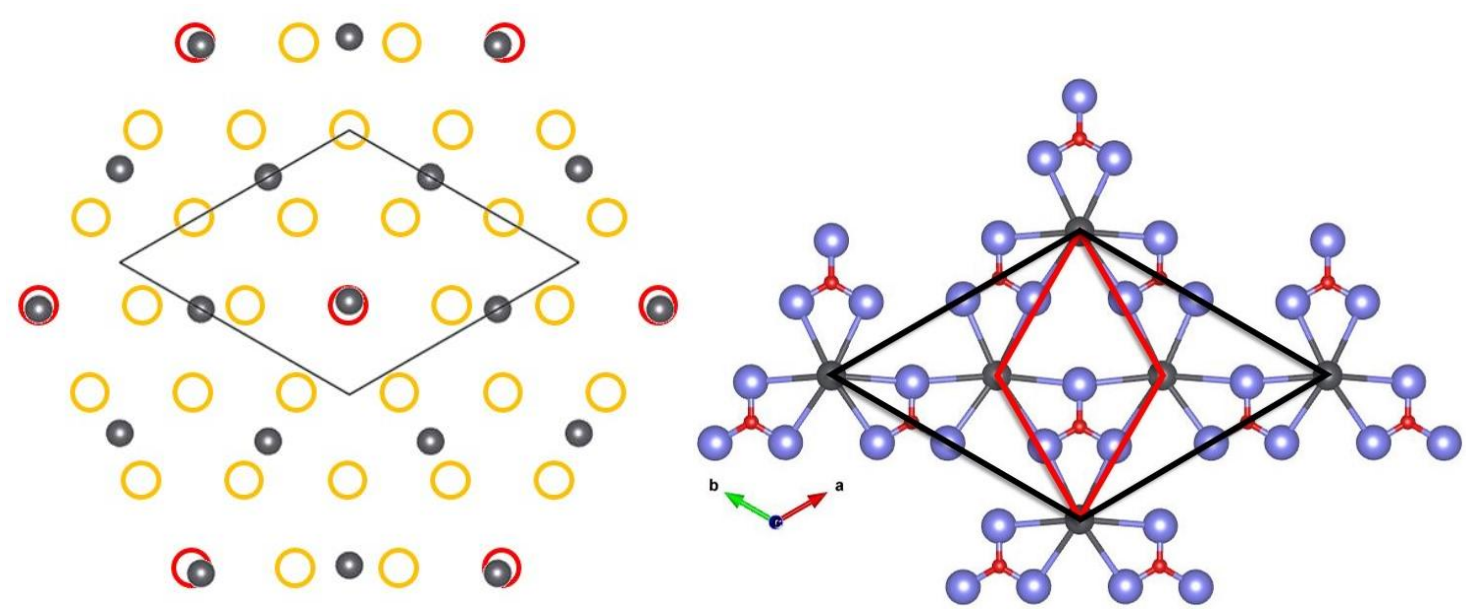

Fig. 5. Epitaxial relationships involving PN. Left: atomic positions in the (111) plane of the $\mathrm{Pb}$ cubic close packing (colored circles) and $\mathrm{Pb}^{\mathrm{II}}$ sublattice at $z \approx 0.3$ in $\mathrm{PN}$ (grey). Right: (001) projection of the $z \approx 0.3$ layer in PN (black cell outline) corresponding to the $z \approx 0.2$ layer in $\mathrm{HC}$ (red outline), with $\mathrm{Pb}$ (grey), $\mathrm{C}$ (red) and $\mathrm{O}$ (blue).

The extreme rarity of PN in paint layers is in agreement with its quasi absence in the flakes. For instance, it proved to be absent from all the 30 fragments sampled from preparation and pictorial layers of the $15-19^{\text {th }}$ centuries masters' paintings we have recently analyzed using synchrotron diffraction [7,9]. Its most notable occurence was ascribed to the degradation of an orange lead pigment in a van Gogh painting [31], therefore not resulting from the LW synthesis. On the other hand, PN recently detected in a lead soap turned out to result from the long-term degradation of $\mathrm{PbO}$ [32].

However, the analysis of two $19^{\text {th }} \mathrm{c}$. raw LW samples issued from the collections of the National Museum of Scotland, Edinburgh, UK (Fig. 6), gave us the opportunity to observe abundant amounts of PN issued from the stack process. These rare pigments (dated from 1867 and referenced T.1867.61.38 and T.1867.61.41), were originally labelled: "One of a collection of specimens illustrating lead manufacture - a wicket (\#38) and a star (\#41) of lead from the stack process, partially converted into white lead". In both cases, the sample still consisted in partly corroded lead, with adherent and non-adherent white powder. The faint volume of the samples only allowed a micro-XRD analysis, leading to a coarse assessment $( \pm 10 \%)$ of the composition as follows:

- $\quad$ non-adherent powder: $\mathrm{HC}: \mathrm{C}=89: 11$ to $99: 1 \mathrm{w} \%, \mathrm{PN}=0 \mathrm{w} \%$

- lead-adherent powder: $\mathrm{PN}: \mathrm{HC}=42: 58$ to $60: 40 \mathrm{w} \%, \mathrm{C}<1 \mathrm{w} \%$ 


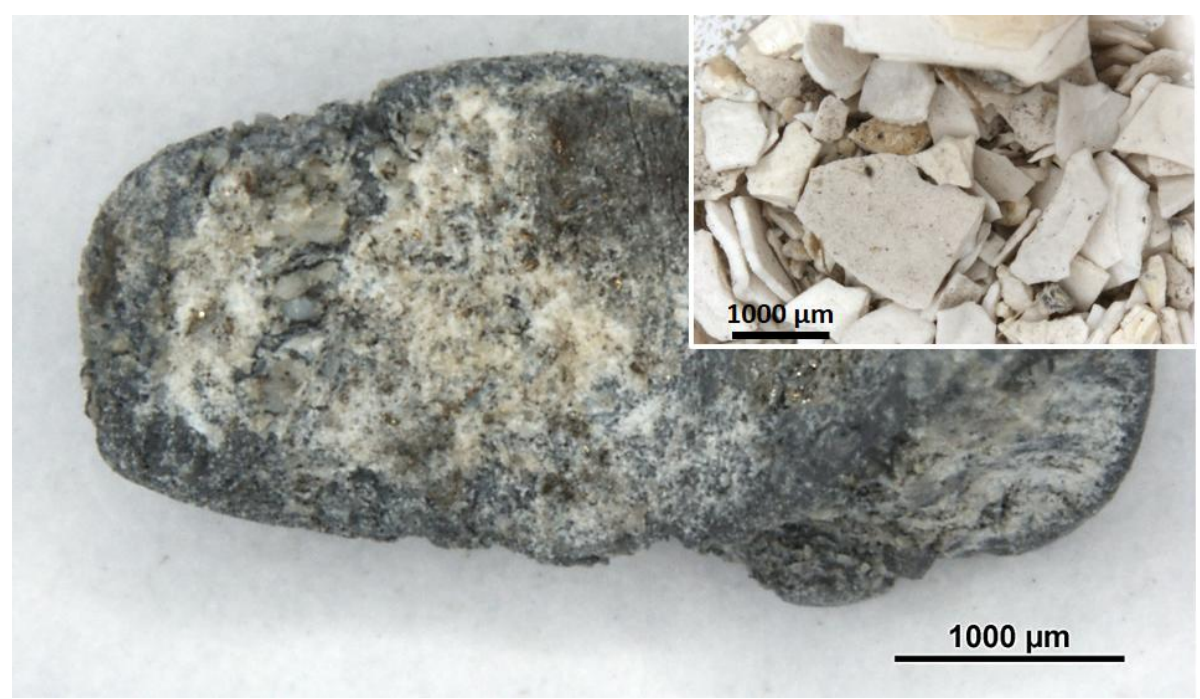

Fig. 6. $19^{\text {th }}$ c. samples from the National Museum of Scotland featuring metallic and corroded lead (references T.1867.61.38 and T.1867.61.41): lead foil with LW traces and flakes (inlay).

While the HC-rich non-adherent powder is similar to the pigments commonly found in the $19^{\text {th }}$ c. paintings $[7,9]$, the material adhering to the lead exhibits a very unusual PN ratio (Fig. 7). So far, we can suggest that the outstanding composition of these historical pigments results of the a posteriori evolution of an incompletely corroded batch, according to reactions 7 and 8. This route is atypical however, so the use of such a PN-rich pigment seems unlikely in easel painting. Nevertheless, these occurences account for the stability of PN over time and its possible growth from $\mathrm{HC}$ or $\mathrm{C}$ in basic media. In particular, the evolution of $\mathrm{C} / \mathrm{HC}$ pigments in $\mathrm{PbO}$-siccatived fatty acid binders could possibly lead to the presence of $\mathrm{PN}$ in paint layers, an hypothesis which calls for further explorations of Old masters' artworks. 


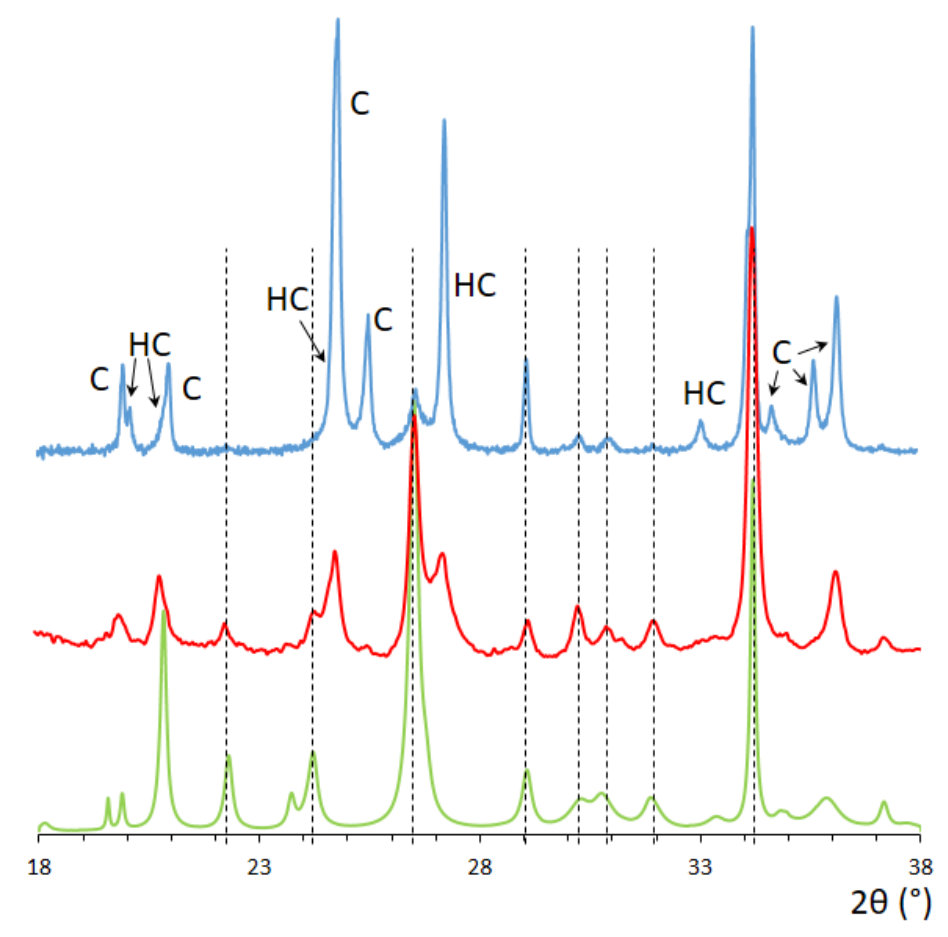

Fig. 7. XRD patterns showing the presence of PN in historical sample T.1867.61.38 (middle, red) and a 3 months mock-up (top, blue), compared to PN grown in the early stages of lead corrosion (bottom, green). Dashed lines show the main discriminant peaks for PN.

To further build on that, a LW sample obtained through reconstruction of the ancient stack process by A. Wallert at the Rijksmuseum (Amsterdam, NL) was analyzed with XRD. The raw pigment was obtained by heavily scraping the partially corroded lead foils. It thus contained dark particles of uncorroded lead, ripped off from the foil, along with a substantial amount of PN. It was then rinsed with water and filtered until separation of the white powder and metallic lead fragments. The result was a disappearance of PN. One can thus infer that PN was strongly bound to lead particles, because of the above-mentioned epitaxial relationship. As raw LW from the stack process was most probably always rinsed to get rid of any dark material tarnishing the pigment's desired white color (dirt or uncorroded lead), the absence of $\mathrm{PN}$ in historical pigments would thus be explained.

Hydrocerussite Among the three carbonation reactions that take place simultaneously during corrosion, $\mathrm{PN}-\mathrm{HC}$ is by far the less limited by the gas supply owing to the very low $\mathrm{CO}_{2}: \mathrm{Pb}$ ratio involved: $1: 15$, whereas the formation of $\mathrm{PN}$ requires 9 times more $\mathrm{CO}_{2}$. This is probably why $\mathrm{HC}$ readily forms short after carbonation starts, and co-exists with PN as long as some metal remains.

From XRD, the HC platelets also appear to grow parallel to the substrate during the early stages of the corrosion, but unlike the fortuitous Pb-PN lattice matching, the PN-HC epitaxy is favored by the strong structural similarity of the structures: both phases show a three-fold symmetry ( $\mathrm{PN}$ is hexagonal, $\mathrm{HC}$ is trigonal) and very similar $\left[\mathrm{PbCO}_{3}\right]$ layers $(3$ independent ones in PN, 1 in HC, Fig. 5, right)). In the (001) plane, $\mathrm{PN}$ and $\mathrm{HC}$ only differ by an $a_{\mathrm{PN}} / a_{\mathrm{HC}}=1.73 \approx \sqrt{3}$ superstructure resulting from the $\boldsymbol{a}_{\mathrm{PN}} \approx 2 \boldsymbol{a}_{\mathrm{HC}}+\boldsymbol{b}_{\mathrm{HC}}$ cell change. More generally, PN and $\mathrm{HC}$ were recently shown to belong to a same wide family of crystal 
structures built upon alternate sheets of neutral $\left[\mathrm{PbCO}_{3}\right]$ separated from other functional groups by the stereochemical activity of the $\mathrm{Pb}^{2+}$ 6s lone pair [33].

Before turning into $\mathrm{C}$, the HC platelets of the flakes' external surface still exhibit the initial (001) texturation (Fig. 8a). However, those grown afterwards, that is, beneath the surface, pile up into twisted columns with both a frequent cyclic $30^{\circ}$ twinning and a marked misorientation of the (001) planes, resulting in a low-compacity sandrose-like microstructure (Fig. 8b). This disordered array of thin crystallites $\left(L_{c} \approx 100 \mathrm{~nm}\right)$ could result from the fast growth kinetics allowed by the the low dependence of the PN-HC conversion towards the $\mathrm{CO}_{2}$ supply. This has important implications regarding the manufacturing of the pigment: on the one hand, the gases diffusion to the metal surface remains fast enough even through a thick layer, thus allowing a complete corrosion of a lead foil within a few weeks as reported in the ancient writings [12]; on the other hand, the pigment organizes into flakes that peel off readily from the metal and make its collection easy.

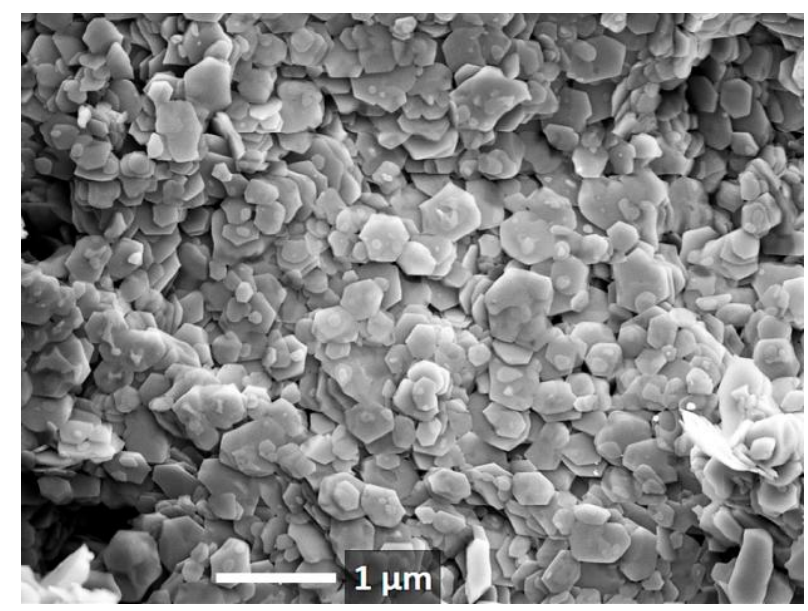

Fig. 8a. Outer side of a flake, showing the (001) faces of the HC crystallites.

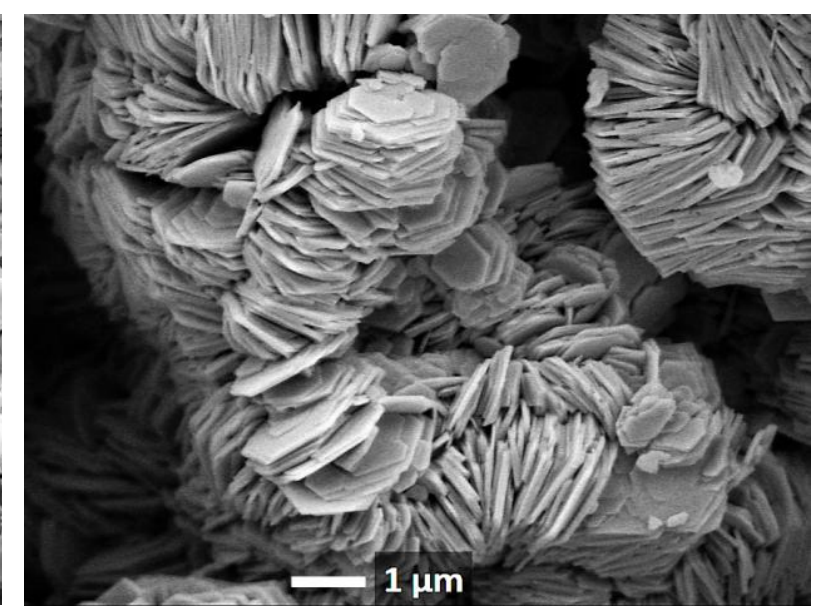

Fig. 8b. Inner side of a flake, showing the disordered array of the HC crystallites.

Cerussite The final product of the corrosion process consists in micron-sized crystallites showing the usual [001] prismatic habitus (Fig. 9). The pseudohexagonal cross-section is a probable hint for the (110) trilling commonly observed on isostructural (orthorhombic) aragonite $\mathrm{CaCO}_{3}$ [34], but the absence of longitudinal striation lines and the symmetric profile of the XRD lines (Fig. 10) account for a low density of the fault planes, in agreement with the slow growth process. On the contrary, the $\mathrm{C}$ powders obtained by precipitation in water, even matured in the mother solution, systematically feature asymmetric Lorentz tails (towards high $2 \theta$ for $h>k$, low $2 \theta$ for $h<k$ ), a typical signature for fast-grown densely faulted polycrystals. This marked difference could provide a quick and reliable differentiation criterium for determining the way a LW was synthesized. 


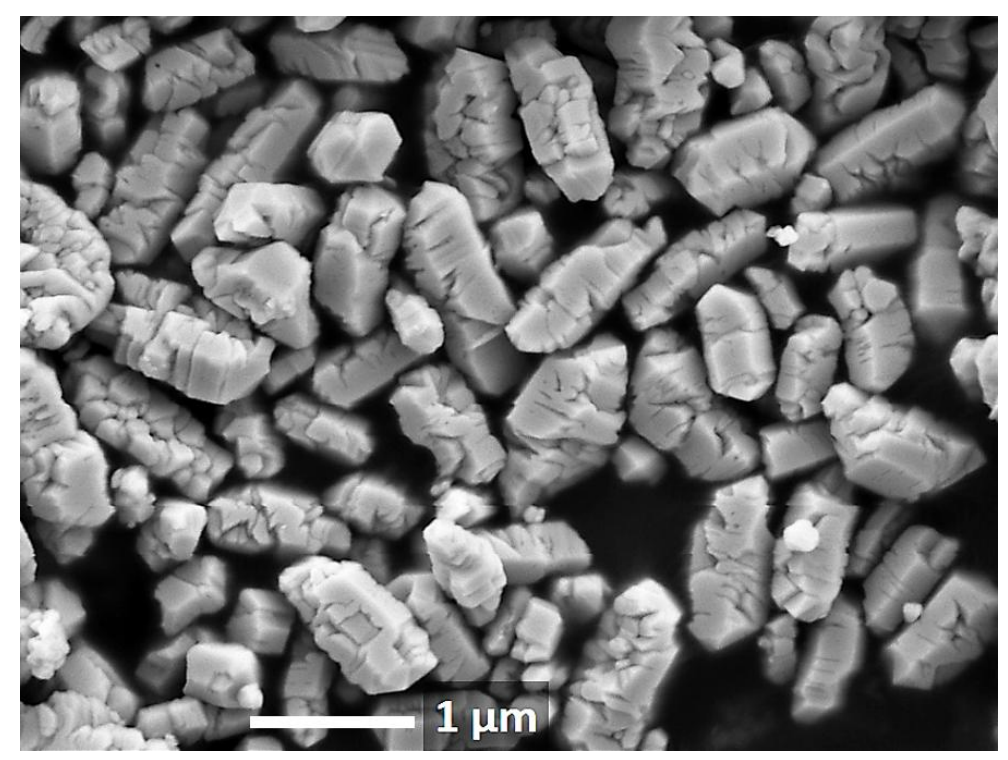

Fig. 9. SEM view of C crystallites obtained by complete corrosion of lead.

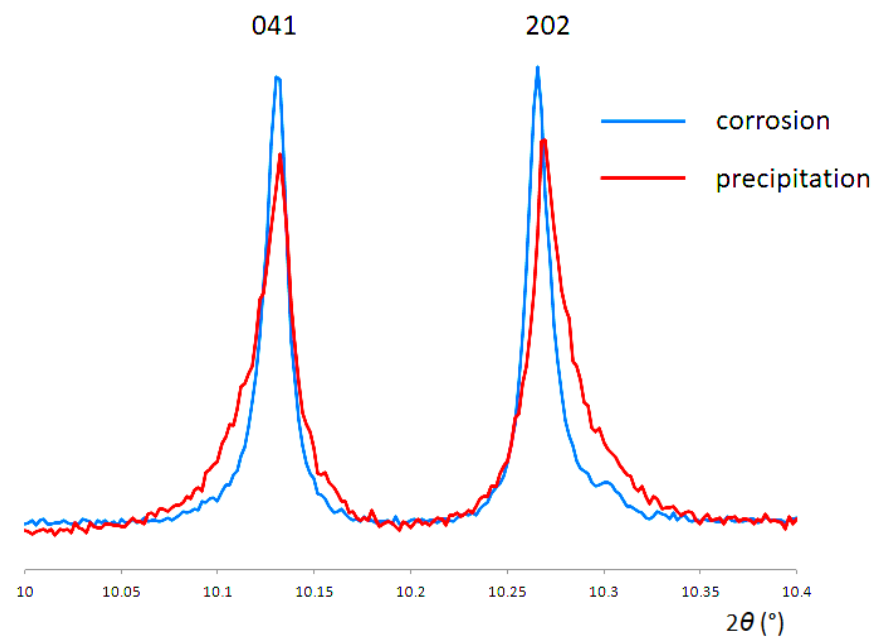

Fig. 10. Comparison between the synchrotron XRD peaks (ESRF ID22, $\lambda=0.35 \AA$ ) of two pure cerussite samples synthesized by corrosion and precipitation. Note the asymmetric broadening for the latter.

Mixed HC/C compositions in pigments The LWs found in Hellenistic and Greek cosmetics [1], Middle-Ages, Renaissance, classic and modern easel paintings [7-9] or in $19^{\text {th }}$ c. preparatory layers [36] underwent very different conditions of preparation, resulting in different original compositions, but almost all of them (except for some cosmetics only made of C) contain both $\mathrm{C}$ and HC. The exitence of mixed compositions over centuries- or millenialong timescales and in various environments is also a point of interest, considering that a mixture of solids based on the same constituents cannot be the result of a thermochemical equilibrium.

Possible long-term transformations resulting from environmental factors must then be considered. In easel paintings, $\mathrm{HC}$ could conceivably have turned into $\mathrm{C}$ after admixture with 
the binder, typically a fatty acid. Despite the global decrease of the HC ratio with time [9] seems to confirm this hypothesis, several samples collected on Renaissance paintings still exhibit very high $\mathrm{HC}$ ratios, thus proving that this phase does not interact significantly with the binder, even on a five-century timescale. Besides, LW cosmetic powders free of organic binder of the Greek-Roman period were also found to consist in $\mathrm{C} / \mathrm{HC}$ mixtures [1], leading to conclude that long-term exposure to atmospheric $\mathrm{CO}_{2}$ can neither be invoked. To ascertain this hypothesis, we observed by XRD that a $\mathrm{HC}$ sample left open to air $\left(\sim 600 \mathrm{ppm} \mathrm{CO}_{2}\right)$ was still free of $\mathrm{C}$ after 26 months. So, despite its tendency to carbonate into $\mathrm{C}$, HC seems to be poorly sensitive to $\mathrm{CO}_{2}$ in atmospheric conditions.

Therefore, the manufacturing process itself must be considered. The most common ancient post-synthesis treatment consisted in washing or grinding raw LW first in vinegar to make it whiter [12], probably to dissolve residual metal, but also resulting in the partial conversion of $\mathrm{HC}$ into $\mathrm{C}$. Subsequent washing in water probably aimed at eliminating soluble lead acetate, but unless carried out in warm water (a rare process), no significant hydrolysis of $\mathrm{C}$ into $\mathrm{HC}$ resulted, according to our experiments. So, the prevalent HC-rich compositions probably do not result from post-synthesis treatments.

More probably, the mass balance of the corrosion process itself is at issue: basically, the synthesis of $\mathrm{HC}$ requires $2 / 3 \mathrm{CO}_{2}$ molecule per lead atom vs. $1 \mathrm{CO}_{2}$ molecule per lead atom for C. In other terms, $1 \mathrm{~mol} \mathrm{CO}$ either yields $40.75 \mathrm{~cm}^{3} / 267.2 \mathrm{~g}$ of C or $56.58 \mathrm{~cm}^{3}$ / $386.8 \mathrm{~g}$ of HC. So, growing C instead of HC would curtail the LW production by $28 \%$ in terms of volume, $31 \%$ in terms of weight. Consequently, one can guess why for the sake of profit, the manufacturers in the past did not wait for a complete carbonation into $\mathrm{C}$, but rather collected the pigment by scraping it off the lead substrate, thus ensuring a high $\mathrm{HC}$ rate. This was reported by several sources through the times, like Heraclius and the monk Theophilus (Middle Ages), La Hire ( $18^{\text {th }}$ c.), Field $\left(19^{\text {th }}\right.$ c.) [12]. Let us keep in mind however that the two phases can hardly be distinguished from each other without modern analytical methods, making the monitoring of the HC-C reaction at least very difficult. Besides, as we saw, the corrosion layer is not homogeneous, which means that some $\mathrm{C}$ already grows at the external surface while some uncorroded lead still remains, thus accounting for the final composition of the pigment. At last, if a high $\mathrm{HC}$ ratio can be considered as a criterion of efficiency, it seems from its continuous increase with time [7-9] that the stack process underwent significant improvements or a better control between the Renaissance period and the late $19^{\text {th }}$ century.

\section{Conclusion}

The experimental process implemented in this work cannot pretend to reproduce faithfully the stack process, in particular concerning variable parameters like temperature, gases concentrations, or even the presence of other decomposition gases. Nevertheless, the time evolution, flakes texture and heterogeneous $\mathrm{C}-\mathrm{HC}$ composition of the corrosion product are in good agreement with the ancient texts and the historical materials, either raw or in pictorial materials. For a complete understanding of the composition and microstructure of the LW pigments in the materials of the cultural heritage, further investigations are needed to understand the effect of the wet processes implemented in post-synthesis treatments and alternative synthesis routes of this material.

\section{Acknowledgements}


The authors are greatly indebted to Dr Lore Troalen of the National Museum of Scotland (Edinburgh, UK) who provided them with the historical LW samples and to Dr Arie Wallert of the Rijksmuseum (Amsterdam, the Netherlands) for the stack process sample. They also wish to thank Nicolas Debon (ENS), Alexandra Dumazet and Emile de Wilde (ENSCP Chimie ParisTech) for their precious help during their trainee period.

\section{Data availability}

The raw/processed data required to reproduce these findings cannot be shared at this time due to technical or time limitations.

\section{References}

[1] E. Welcomme, P. Walter, E. van Elslande, G. Tsoucaris, Investigation of white pigments used as make-up during the Greco-Roman period, Appl. Phys. A 83 (2006) 551-556.

[2] T. Katsaros, I. Liritzis, N. Laskaris, Identification of Theophrastus' pigments egyptios kyanos and psimythion from archaeological excavations: A case study, ArcheoSciences, Revue d'Archéométrie 34 (2010) 69-79.

[3] Theophrastus of Eressos, De Lapidus, Ed. and trans. D. E. Eichholz, the Clarendon Press, Oxford, 1965.

[4] Pliny the Elder, Historiae Naturalis, XXXIV, Teubner, Leipzig, 1897.

[5] J. Salvant, J. Williams, M. Ganio, F. Casadio, C. Daher, K. Sutherland, L. Monico, F. Vanmeert, S. De Meyer, K. Janssens, C. Cartwright, M. Walton, A Roman Egyptian Painting Workshop: Technical Investigation of the Portraits from Tebtunis, Egypt, Archaeometry, 60 (2018) 815-833.

[6] E. Welcomme, P. Walter, P. Bleuet, J.-L. Hodeau, E. Dooryhee, P. Martinetto, M. Menu, Classification of lead white pigments using synchrotron radiation micro X-ray diffraction, Appl. Phys. A 89 (2007) 825-832.

[7] V. Gonzalez, T. Calligaro, G. Wallez, M. Eveno, K. Toussaint, M. Menu, Composition and microstructure of the lead white pigment in Masters paintings using HR Synchrotron XRD, Microchem. J. 125 (2016) 43-49.

[8] V. Gonzalez, T. Calligaro, L. Pichon, G. Wallez, B. Mottin, Leonardo da Vinci's drapery studies: characterization of lead white pigments by a mu-XRD and 2D scanning XRF, Appl. Phys. A 121 (2015) 849-856.

[9] V. Gonzalez, G. Wallez, T. Calligaro, M. Cotte, W. de Nolf, M. Eveno, E. Ravaud, M. Menu, Synchrotron-based high angle resolution and high lateral resolution X-ray diffraction reveals lead white pigment pigment qualities in Old Masters paintings, Anal. Chem. 89 (2017) 13203-13211.

[10] R.D. Harley, Artists' Pigments c.1600-1835, a study in English documentary sources, $2^{\text {nd }}$ revised ed, Archetype Publications, London, 1982. 
[11] M. Niknejad, A.-H. Karimy (2018) Lead white or lead whites? Reconsideration of methods of sefidāb-i-sorb production in Iran, Stud. Conserv. (2018), DOI: $\underline{10.1080 / 00393630.2018 .1457290 .}$.

[12] M. Stols-Witlox, The heaviest and the whitest: lead white quality in north western European documentary sources, 1400-1900, Archetype Editions, London, 2011.

[13] A.H. Sabin, White Lead - Its use in paint, John Wiley \& Sons, Inc, New York, 1920.

[14] J. Tétreault, J. Sirois, E. Stamatopoulou, Studies of lead corrosion in acetic acid environment, Stud. Conserv. 43 (1998) 17-32.

[15] A. Niklasson, L.G. Johansson, J.E. Svensson, Influence of acetic acid vapor on the atmospheric corrosion of lead, J. Electrochem. Soc. 152 (2005) B519-B525 .

[16] A. Niklasson, L.G. Johansson, J.E. Svensson, The influence of relative humidity and temperature on the acetic acid vapour-induced atmospheric corrosion of lead, Corros. Sci. 50 (2008) 3031-3037.

[17] A.N. Campbell, E.M. Kartzmark, J.M.T.M. Gieskes, Vapor-liquid equilibria, densities, and refractivities in the system acetic acid-chloroform-water at $25{ }^{\circ} \mathrm{C}$, Can. J. Chem. 41 (1963) 407-429.

[18] W.A. Dollase, Correction of intensities for preferred orientation in powder diffractometry: application of the March model, J. Appl. Cryst. 19 (1986) 267-272.

[19] J. Rodriguez-Carvajal, FULLPROF: A Program for Rietveld Refinement and Pattern Matching Analysis, Abstracts of the Satellite Meeting on Powder Diffraction of the XV Congress of the IUCr, p. 127, Toulouse, France (1990).

[20] G. Chevrier, G. Giester, G. Heger, D. Jarosch, M. Wildner, J. Zemann, Neutron singlecrystal refinement of cerussite, $\mathrm{PbCO}_{3}$, and comparison with other aragonite-type carbonates, Z. Kristallogr. 199 (1992) 67-74.

[21] P. Martinetto, M. Anne, E. Dooryhee, P. Walter, G. Tsoucaris, Synthetic hydrocerussite, $2 \mathrm{PbCO}_{3} \cdot \mathrm{Pb}(\mathrm{OH})_{2}$, by X-ray powder diffraction, Acta Crystallogr. C58 (2002) 82-84.

[22] S.V. Krivovichev, P.C. Burns, Crystal chemistry of basic lead carbonates. II. Crystal structure of synthetic 'plumbonacrite', Mineral. Mag. 64 (2000) 1069-1075.

[23] A. Hammersley, S.O. Svensson, M. Hanfland, A.N. Fitch, D. Haüsermann, Twodimensional detector software: From real detector to idealised image or two-theta scan, High Press. Res. 14 (1996) 235-248.

[24] W. Kwestroo, C. Langerei, Basic Lead Acetates, J. Inorg. Nucl. Chem. 27 (1965) 25332536.

[25] R. Faivre, R. Weiss, Composés du Plomb et de l'Oxygène, in Nouveau Traité de Chimie Minérale, 7, Masson \& Cie, Paris, 1963.

[26] Vitruvius, De Architectura, English translation: The Ten Books on Architecture, Morris Hicky Morgan, Oxford University Press, Oxford, 1914. 
[27] Pedanius Dioscorides of Anazarbus, De Materia Medica, transl. Lily Y Beck, Altertumswissenschaftliche Texte und Studien 38, Olms-Weidmann, Hildesheim, 2005.

[28] D.V. Thompson, The Materials and Techniques of Medieval Paintings, George Allen \& Unwin Ltd, London, 1956.

[29] M. Clarke, Writing recipes for non-specialists c.1300: the Anglo-Latin Secretum philosophorum, Glasgow MS Hunterian 110, Sources and Serendipity: Proceedings of the third symposium of the Art Technological Source Research Working Group, Archetype Publications, London, 2009.

[30] F.J. Martínez-Casado, M. Ramos-Riesco, J.A. Rodriguez-Cheda, F. Cucinotta, E. Matesanz, I. Miletto, E. Gianotti, L. Marchese, Z. Matej, Unraveling the Decomposition Process of Lead(II) Acetate: Anhydrous Polymorphs, Hydrates, and Byproducts and Room Temperature Phosphorescence, Inorg. Chem 55 (2016) 8576-8586.

[31] F. Vanmeert, G. van der Snickt, K. Janssens, Plumbonacrite identified by X-ray powder diffraction tomography as a missing link during degradation of red lead in a van Gogh painting, Angew. Chem. Int. Ed. 54 (2015) 3607-3610.

[32] M. Cotte, E. Checroun, W. de Nolf, Y. Taniguchi, L. de Viguerie, M. Burghammer, P. Walter, C. Rivard, M. Salomé, K. Janssens, J. Susini, Lead soaps in paintings: Friends or foes?, Stud. Conserv. 62 (2016) 2-23.

[33] O. Siidra, D. Nekrasova, W. Depmeier, N. Chukanov, A. Zaitsev, R. Turner, Hydrocerussite-related minerals and materials: structural principles, chemical variations and infrared spectroscopy, Acta Crystallogr. B 74 (2018) 182-195.

[34] M. Suzuki, H. Kim, H. Mukai, H. Nagasawa, T. Kogure, Quantitative XRD analysis of $\{110\}$ twin density in biotic aragonites, J. Struct. Biol. 180 (2012), 458-468.

[35] M.J. Buerger, Crystal-structure analysis (1960), John Wiley \& Sons, New York.

[36] E. Ravaud, M. Eveno, T. Calligaro, V. Gonzalez, G. Wallez, W. Nowik, J. Aufort, Study of a pre-primed canvas bundle from the Binant color merchant, ICOM-CC $17^{\text {th }}$ Triennal Conference Preprints (2014) art. 102. 